\title{
Public Attention, Governmental Bargaining, and Supranational Activism: Explaining European Integration in Response to Crises*
}

\author{
HANNO DEGNER (iD)
}

University of Konstanz

\begin{abstract}
Why and how do crises cause European integration? Going beyond case- and policy area-specific analyses, the present paper develops a general, liberal intergovernmentalist model of the crisis-integration link. The empirical process-tracing test of this model is performed on two diverse cases of crises: the BSE Crisis 1996-2002 and the Euro Crisis 2010-13. The original analysis of primary documents and newspaper articles reveals that, as theoretically expected, crises stir high public attention and thus turn policy change in the affected policy areas into a salient issue for governments. This opens a 'window of opportunity' for domestic actors to approach their governments with change proposals. Governmental cost-benefit calculations, the distribution of bargaining power at the EU level, as well as supranational activism then explain deeper European integration in response to a crisis. With these findings, the present paper contributes to a broader understanding of the mechanisms of European integration in exceptional times.
\end{abstract}

Keywords: European integration; causal mechanisms; case studies; liberal intergovernmentalism; governments

\section{Introduction: Crises and European Integration}

The European Union (EU) ${ }^{1}$ is in deep trouble. Twenty-five years after the signature of the Maastricht treaty, the simultaneity of lasting economic instability and high unemployment in many Member States, mass migration, recurring terrorist attacks, growing rightwing populist movements, as well as violent conflicts and outright wars in its direct neighbourhood put the European polity to the most serious test in its history. Will the Union pass it?

Worried europhiles may find some hope in the EU's history. In the last decades, European politicians continuously decided to deepen European integration in crisis-affected policy areas (Schmitter, 2012, p. 39; Stone Sweet, 2004, p. 236f). Despite growing fears of European disintegration in recent years (Vollard, 2014; Webber, 2017), this trend has not reversed so far (see Dinan et al., 2017, p. 369ff). Even the recent Schengen crisis resulted in (reluctant) steps towards deeper integration, such as the

* The author would like to express gratitude to Dirk Leuffen, Hakan Günaydin, Gijs Jan Brandsma, and the anonymous JCMS referees of this article for their detailed and immensely helpful comments. For comments on earlier versions, I thank Ariadna Ripoll Servent, Isabel Winnwa, Scott Brown and the audiences at the ECPR SGEU Pan-European Conference on the European Union 2016, the ECPR General Conference 2016, and the ISA Annual Convention 2017.

${ }^{1}$ Being aware of the differences between the European Economic Community (EEC), the European Communities (EC), and the European Union (EU), this paper uses the latter term throughout the manuscript to signify the European polity that was founded in 1957 with the Rome treaties. 
set up of Europol's new European Counter Terrorism Centre in The Hague (Trauner and Ripoll Servent, 2016). The potential British departure from the EU, in turn, primarily concerns 'horizontal' European integration; 'vertical' integration in the remaining 27 Member States is not directly affected (for the concepts, see Leuffen et al., 2013). In fact, 'Brexit' has already stirred debates about deeper vertical integration in the remaining EU-27 in various policy areas, including security policy or the 'digital single market'.

But why and how exactly do crises cause European integration? So far, the regional integration literature does not provide a comprehensive theoretical answer to this question (Leuffen et al., 2013, p. xiii; Saurugger, 2016). While the impact of economic crises on regional integration in fiscal and monetary policy has been subject to intensive scrutiny in recent years (see, for example, Ioannou et al., 2015; Saurugger and Terpan, 2016; and Tosun et al., 2014), the often very case- and/or policy-area specific hypotheses undermine the travel potential of the respective theoretical models to other policy areas.

By developing a general, four-part model of the crisis-integration link, the present paper thus aims to close an important research gap. The model is mainly based upon liberal intergovernmentalism (LI) (Moravcsik, 1993, 1998), which has established itself as a 'baseline theory' in the regional integration literature (Moravcsik and Schimmelfennig, 2009, p. 67). It explains European integration as a series of rational choices made by national governments in response to international interdependence. Yet, the theory does not discuss the impact of high public attention, ambiguity and time constraints, which characterize decision-making in crisis situations (Saurugger, 2016, p. 958). In order to complement LI with regard to these elements, the present study draws on insights of the multiple streams framework (MSF) (Kingdon, 2003 [1984]), which has become increasingly prominent in EU studies recently (Ackrill et al., 2013).

The theoretical model expects crises to stir public attention, turning policy change in the respectively affected policy area into a highly salient issue for governments. This opens a window of opportunity for domestic actors, which approach 'their' governments with change proposals. Governmental cost-benefit calculations regarding these proposals, the distribution of governmental bargaining power on the EU level, as well as supranational activism then explain deeper European integration in response to the crisis.

To test these theoretical claims, the paper conducts two empirical case studies on severe crises that affected the Union and its Member States after Maastricht: the BSE Crisis 1996-2002, and the Euro Crisis 2010-13. While the BSE Crisis impacted on integration in consumer protection and public health policy, which are related to the EU's internal market (Knowles et al., 2007; Vos, 2000), the Euro Crisis mainly affected important 'core state powers', namely fiscal and economic policy (Genschel and Jachtenfuchs, 2013; Schimmelfennig, 2015b). The analysis of the two cases, which is based on 'theory-testing process-tracing' methods (Beach and Pedersen, 2013), largely fits the theoretical expectations. The concluding chapter summarizes the findings and calls for further comparative research on the causal mechanisms that link crises to European integration.

${ }^{2}$ See http://www.consilium.europa.eu/en/press/press-releases/2016/09/16-bratislava-declaration-and-roadmap. 


\section{Theory: A Four-Part Mechanism Linking Crises to European Integration}

Why and how do crises cause European integration? The present paper argues that a fourpart causal mechanism (Hedström and Ylikoski, 2010, p. 50f) links the former to the latter.

\section{Part I: Policy Change Becomes a Salient Issue for Member State Governments}

The first part of this mechanism concerns agenda-setting. While this stage of the policy cycle is only vaguely discussed in Moravcsik's LI framework (1998, p. 50), it is a central element of the MSF (Kingdon, 2003[1984], p. 94ff). When the EU faces a 'transboundary' crisis, many citizens across many Member States perceive the presence of three elements: a severe threat for material or immaterial values, a sense of urgency to resolve that threat, and an unusually high degree of uncertainty about both the exact nature of the threat and the consequences of the decisions taken to counter it (Boin et al., 2005). The sudden presence of such a situation immediately directs public attention to the underlying problems in the affected policy area.

High public attention in times of crisis goes hand in hand with an urgent public demand for crisis resolution (Kingdon, 2003 [1984], p. 94ff). The notion of crises as 'the hour of the executive' (Lodge and Wegrich, 2012, p. 1) implies that re-election seeking national governments usually resort to quick executive action in response to such a demand. Because of the high interdependence in the EU, however, Member State governments are usually unable to unilaterally resolve transboundary crises (Boin and Rhinard, 2008). At the same time, European integration has not resulted in a fully-fledged EU crisis management capacity in most policy areas so far (Larsson et al., 2009, p. 6; Missiroli, 2006, p. 433f). By contrast, the EU's founding fathers 'did not conceive it as a crisis management institute and thus neither them nor their followers designed built-in organizational capacities to mitigate and respond to crises' (Boin et al., 2013, p. 10). Member State governments facing a transboundary crisis therefore conceive legislative policy change in the affected policy area as a highly salient issue (cf. Zahariadis, 2014, pp. 28-30).

H1 High public attention turns policy change in the crisis-affected policy area into a highly salient issue for Member State governments.

In order to test this hypothesis, we should observe governments as they engage in legislative activities in reaction to high public attention for the policy area in crisis. Legislative activities are mirrored in an unusually high frequency of intergovernmental meetings at the highest political level, during which the EU's heads of state and government explicitly call for the adoption of EU primary and/or secondary law changes in the policy area in crisis.

Part II: Domestic Actors Make Use of the Window of Opportunity to Foster (Dis-) Integration

Rising salience of policy change in the affected policy area is expected to open a 'window of opportunity' for domestic actors to approach their governments with 
proposals for policy change in that area (Kingdon, 2003 [1984]). Whether these proposals imply further or less integration depends on the actors' rational cost-benefit calculations.

Following Genschel and Jachtenfuchs (2016, p. 50ff), this study expects the character of the affected policy area - 'core state power' or internal market-related - to determine which actors are most active in the process of 'national preference formation' (Moravcsik, 1998). If a crisis affects 'core state powers' such as fiscal and monetary policy, defence policy, or internal and external security policy, political and societal elites dominate the domestic politics of European integration in response to crises. These elites include national-level politicians, senior national civil servants, media leaders, for example heads of broadcast and print media, and cultural elites, such as persons playing a leading role in the academic, cultural or religious life (European Commission, 1996). By contrast, if a crisis hits policy areas related to the internal market, powerful and well-organized economic interest groups are the most active policy entrepreneurs ( $c f$. Moravcsik, 1998, p. 24ff).

Either way, the chances of an individual actor successfully approaching the government with a proposal are a function of this actor's access opportunities to the government (Moravcsik, 1998, p. 47).

H2a : Well-organized economic interest groups successfully approach national governments with proposals for policy change in policy areas related to the EU's internal market.

H2b : Domestic elites successfully approach national governments with proposals for policy change in policy areas related to core state powers.

Corresponding to these hypotheses, we should observe the respective domestic actors as they approach their governments with policy proposals in direct or indirect ways, for example, through personal meetings, press releases, interviews or advertisements in quality newspapers.

\section{Part III: Governments Perform a Cost-Benefit Analysis of Proposals}

A government's choice for and pursuit of a particular policy proposal depends on two factors: first, the perceived material costs of action versus inactivity, which mainly result from the government's perception of the severity of the looming threat at a given moment in time. Second, governments consider the expected ratification costs of the proposed legislative measures in response to the crisis, which depend on the formal and - more importantly (Moravcsik, 1993, p. 515) - informal ratification power of the relevant domestic actors. The growing politicization of European integration (Hooghe and Marks, 2009) moreover incites re-election seeking governments to take public opinion into account when defining the national preference for the subsequent EU-level negotiations (Genschel and Jachtenfuchs, 2016, p. 52ff). Public dissent increases the informal ratification costs of European integration, especially when the public is highly attentive to the reform proposals on the negotiation table ( $c f$. Boin and Rhinard, 2008, p. 16). 
H3 National governments pursue those proposals that are least materially and electorally costly.

To test this hypothesis, evidence from governmental documents or statements, quality media reports, or scholarly pieces of research needs to show that governments actually assessed different policy proposals with regard to their material and ratification costs.

Part IV: Powerful Member State Governments Determine Interstate Bargaining Results

Even if all EU Member State governments preferred strategies that imply deeper European integration, understood here as the result of a political process in which political representatives of previously sovereign European nation-states voluntarily and repeatedly decide to 'pool' and/or 'delegate' parts of their individual national sovereignty in selected policy areas (Moravcsik, 1993, p. 479), they are likely to oppose each other on the exact distribution of integration costs and benefits. Governments therefore engage in hard intergovernmental bargaining (Moravcsik, 1998, p. 3). The substance and form of the EU's ultimate legislative response to a crisis situation reflects the intergovernmental constellation of bargaining power in EU-level negotiations, which results from asymmetrical interdependence (Moravcsik, 1998, p. 60f). States that are less directly affected by a transboundary threat should thus have a greater power potential to shape the substance and form of European integration in response to a crisis, or to successfully bargain for side payments or opt outs. Beyond that, material power sources like economic strength or technological advantages enhance the bargaining position of a government vis-à-vis its partners (Tallberg, 2008, p. 687).

Once again, the character of the affected policy area induces important variation in the politics of European integration in response to crises. When a crisis affects internal market policies, the supranational EU institutions such as the Commission, the European Parliament, or the European Central Bank should play an important role. By contrast, this role should be much less pronounced when a crisis affects 'core state powers' (Genschel and Jachtenfuchs, 2016; Moravcsik, 1998; Tallberg, 2008).

H4a: Powerful EU Member States and supranational institutions are most influential in the EU-level negotiations that determine the legislative response to crises that affect policy areas related to the EU's internal market.

$H 4 b$ : Powerful EU Member States, but not supranational institutions are most influential in the EU-level negotiations that determine the EU's legislative response to crises that affect policy areas related to core state powers.

Observable implications for this expectation are a high congruence between the negotiation positions of powerful EU Member States and, in case, supranational institutions, and the ultimately adopted primary and secondary EU law changes. The former usually take the form of intergovernmentally convened treaty amendments, whereas the latter include the adoption of high-profile EU directives and regulations. This formal, legal 
operationalization of (vertical) European integration as the result of 'history-making decisions' (Peterson and Bomberg, 1999, p. 10ff) is in line with the integration concept put forward by Leuffen et al. (2013).

\section{Methods, Case Selection and Data}

Causal mechanisms are theoretical constructs. This paper uses the method of 'theory-testing process tracing' (Beach and Pedersen, 2013) to trace the above-presented observable implications of the theoretical expectations in the empirical world. This method is particularly tailored for research problems where conjectures about a positive association between the independent variable (here: crises) and the dependent variable (here: European integration) exist, but knowledge about the exact causal relationship linking the two is lacking. It can moreover be considered the most adequate approach for a systematic in-depth investigation of the key actors, their preferences, actions and interactions in EU decision-making on European integration (Schimmelfennig, 2015a).

In order to ensure a high internal validity of the findings, the empirical investigation of the crisis-integration link will be performed in the framework of a small-n study (Beach and Pedersen, 2013). The study selects two cases from the population of transboundary crises that affected the EU since the signature of the Maastricht treaty in 1992 ( $c f$. Boin et al., 2013; Dinan et al., 2017). ${ }^{3}$ The external validity of the findings will be enhanced through the application of Gerring's (2007) 'diverse case' selection strategy. In view of the limited number of cases and the potentially indefinite number of case-specific context factors this paper cannot control for, one needs to be cautious when generalizing from the results of the case studies (Beach and Pedersen, 2013, p. 152f).

Against the backdrop of these considerations, the study selects two positive cases of crises that both posed a severe threat to the European polity, but affected different policy areas: the BSE Crisis 1996-2001, and the Euro Crisis 2010-13. While the former affected consumer protection and public health policy (internal market policies), the latter primarily hit the policy areas of fiscal and economic policy (core state powers). The analysis does not include a negative case, that is a case in which either a crisis situation or change in European integration are absent, because a meaningful test for the presence and functioning of causal mechanisms is only possible when both the explanans and the explanandum are present (Beach and Pedersen, 2013, p. 147).

The Euro Crisis represents the most severe economic crisis in the EU's history. It threatened the EU with a collapse of its common currency, the Euro, and created high levels of distrust between EU Member States, EU institutions and citizens (Schimmelfennig, 2017). The BSE Crisis, arguably the most severe health crisis in the history of the EU, did not shake the European polity to a similar extent. However, the EU's initial reaction to the crisis - the swift adoption of an export ban on all British cattle and beef products - provoked the British government to pursue a "policy of non-co-operation' (BBC, 1997) from May 1996 onwards. This move led to a blockade of 75 decisions

\footnotetext{
3 The population includes 13 transboundary crises: the Yugoslavian wars 1991-95, the European Monetary System (EMS) Crisis 1992-93, the BSE Crisis 1996-2002, the Kosovo Crisis 1998-99, the Post-9/11 Security Crisis 2001-05, including the Iraq war 2003, the Bird Flu Pandemic 2005-07, the Georgian Crisis 2008, the World Financial and Economic Crisis 2007-09, the Swine Flu Pandemic 2009-10, the Euro Crisis 2010-13, the Arab Spring, in particular the Syrian civil war since 2010, the Schengen Crisis since 2014, and the Ukraine Crisis since 2014.
} 
in the Council, a situation not seen in the EU since the Empty Chair Crisis 1965 (van Middelaar, 2013, p. 106). Moreover, in a rare move, the European Parliament set up a special Committee of Inquiry in September 1996 to scrutinize the EU's (mis)handling of BSE prior to the crisis, and even threatened the Commission with a motion of no confidence for failure to present and adopt reforms in the affected policy areas (European Parliament, 1997). The BSE Crisis and the Euro Crisis are thus considered sufficiently similar to allow for a comparative assessment of the theoretical model developed above.

In order to gain the deepest possible insights into the two cases, the paper follows Moravcsik (1998) in restricting the analysis of domestic preference formation processes to the EU's 'big three' Germany, France and the United Kingdom (UK). Concerning data sources, the present paper mainly relies on primary sources such as official governmental documents, European Council conclusions, and documents by domestic actors, such as press releases. Secondary sources, especially quality newspaper articles and specialized online newspapers like Euractiv.com are used as well. To measure public attention, quantitative data on the media coverage of unveiled problems is generated from quality newspapers (cf. Boin et al., 2005, p. 72). Six of them, a centre-left and a centre-right one from each of the three major EU Member States, are selected: Süddeutsche Zeitung (SZ), Frankfurter Allgemeine Zeitung (FAZ), Le Monde (LM), Le Figaro (LF), The Guardian (TG) and The Financial Times (FT). ${ }^{4}$ Beyond that, secondary academic literature serves as a further data source, as well as for triangulation purposes.

\section{European Integration in Response to the BSE Crisis 1996-2002}

The BSE Crisis unfolded when British Health Minister Dorrell indicated on 20 March 1996 that BSE (bovine spongiform encephalopathy), a fatal neuro-degenerative disease in cattle, and a new variant of the human Creutzfeld-Jacob disease (vCJD) were directly linked (van Zwanenberg and Millstone, 2005, p. 199). While BSE was already detected in the UK in 1986 and several hundreds of thousands of cattle died from the disease in the early 1990s, the extent of the threat posed by BSE for humans remained a non-issue in the public debate until early 1996. The low coverage of BSE in the six British, French and German newspapers under investigation reflects this: every newspaper covered the issue on average about 4.5 times per month in the two years before the outbreak of the crisis. In line with the expectation formulated in , this value jumped to 36.5 articles per month between 1996 and 2002, with peaks in March 1996 (196 articles per newspaper and month) and January 2001 (188 articles). In other words, public attention to the problem of BSE increased markedly.

In response to the markedly increased public attention for the problem of BSE, policy change in the area of food safety and public health, indeed, became a salient issue for national governments after 20 March 1996. This is mirrored in a high number of intergovernmental meetings on the EU level that dealt with BSE, food safety and public health policy from March 1996 onwards, particularly between December 1999 and December 2001. Corresponding to part I of the theoretical model, the European Council discussed these issues in 9 of its 26 officially recorded meetings between March 1996 and

\footnotetext{
${ }^{4}$ The online archives of the newspapers can be found online at: http://www.sspdiz.apa.at (SZ), http://fazarchiv.faz.net (FAZ), http://www.lexisnexis.com/uk/nexis (LM, LF, TG), and http://find.galegroup.com/ftha (FT) (accessed 1 October 2016).
} 
December 2001. Amongst other issues such as the Kosovo crisis 1998-99 and the negotiations on the Amsterdam and Nice treaties, the BSE Crisis contributed to the unusually high meeting frequency of almost 4.5 European Council meetings per year in that period. In 1994 and 1995, by contrast, European leaders only met twice per year and did not discuss BSE. ${ }^{5}$

In their conclusions, chief executives continuously called for the harmonization of legislation in the affected policy area to solve the underlying transboundary problem of BSE in the EU's Single Market for foodstuffs and agricultural products more generally. This marks a shift in the Member States' approach to food safety regulation. Before the BSE Crisis, as Ellen Vos (2000, p. 231) notes, the EU 'had not been designed to deal with risk regulation'.

Corresponding to hypothesis $\mathrm{H} 2 \mathrm{a}$, national preference formation on the European response to the BSE Crisis was mainly driven by the interests of national farmers associations and large retailers that feared the costs of large-scale reforms aiming at BSE eradication and prevention for the food production and agriculture sector (FAZ, 2000). Despite the fact that 'concerns about food security and food quality, particularly in the context if the $[\mathrm{BSE}]$ crisis $[\ldots]$ increased the gap between the preoccupations of farmers and consumers' (Milzow, 2012, p. 30), the degree of organization of farmers, the level of proficiency in defending their interest, and their inclusion into the political process ensured that their preferences were taken up by leading politicians and the government in particular. ${ }^{6}$

The heterogeneity of national producers' interests yet hampered the role of European umbrella organizations like the Comité des organisations professionnelles agricoles (COPA) between 1996 and 2000. As long as BSE was predominantly perceived as a problem that could be resolved through an effective export ban on British beef and cattle products, continental European farmers' associations opposed most reform proposals that aimed at reducing the risk of BSE infections across the EU. Instead, they lobbied for the prevalence of the status quo. Although the mishandling of BSE before 1996 undermined public trust in the European Commission (Vos, 2000, p. 228), Member State governments (Beck and Asenova, 2007, p. 8), and the European integration project in general (Clergeau, 2005, p. 121), the French and German governments tried to avoid an open conflict with 'their' farmers and the high ratification costs that further integration in EU food safety policy would correspondingly imply (see also Milzow, 2012, p. 33ff).

The strong public demand for reforms after 2000 in France and Germany changed the governmental cost-benefit analyses of the integration proposals on the table (Fischer, 2009, p. 92; Krapohl and Zureck, 2006, p. 11). When the necessity of a joint European response to the crisis became undeniable in view of the outbreak of BSE in native French and German cattle (Krapohl and Zureck, 2006, p. 12), the governments of the two largest continental economies discarded the proposals of the status quo oriented domestic agriculture associations, and fostered integration corresponding to proposals put forward by consumer associations and the European institutions instead. German Chancellor Schröder correspondingly stated on 11 January 2001 that the positions of agricultural

\footnotetext{
${ }^{5}$ See the European Council conclusions at http://www.consilium.europa.eu/en/european-council/conclusions/1993-2003/.

${ }^{6}$ An example for the influence of agriculture associations in Germany can be found at http://www.faz.net/aktuell/politik/ stamm-ruecktritt-das-aus-fuer-die-maechtigste-frau-der-csu-116581.html.
} 
associations were still taken seriously, but that consumer interests would 'from now on be given priority' (FAZ, 2001).

This shift in the perception of the threat and the perceived costs of countering it is also mirrored in interstate bargaining on resolving the BSE Crisis. The first phase of negotiations between 1996 and 2000 took place in the context of the tense political conflict on (the potential lifting of) the worldwide export ban on British beef and cattle products. Due to the status quo orientation of most EU Member States, national governments did not adopt important acts of European integration in that time period, with one exception: in 1997, the Amsterdam treaty enhanced the EU's formal competencies in the area of public health (Art. 152 TEC, today Art. 168 TFEU) (cf. Mayer, 2004, p. 24). This, however, did not have immediate effect on the governance of food safety across the EU.

By contrast, after the perception change of the BSE threat in 2000, consumer interests were valued higher than those of farmers' associations, so that reforms in the affected policy areas became possible. In line with hypothesis H4a, the European institutions, notably the European Parliament and the Commission, significantly influenced EU decision-making in 2001-02. As Clergeau (2005, p. 122) notes: 'Parliament and the Commission formed a real partnership to steer the reform process'. By 1997, the Commission had already taken up many of the 70 proposals of the European Parliament's Medina Ortega Report on reforms of food safety governance (European Parliament, 1997) in its Green Paper on the general principles of food law (European Commission, 1997). With its subsequent White Paper of January 2000, the Commission (2000) prepared the blue prints for the General Food Law and the European Food Safety Authority (EFSA). These proposals aimed at increasing transparency in the fight against BSE, institutionalizing controls and inspections in the area of food safety, and ensuring consumer protection and the restoration of the single market in foodstuffs. The General Food Law and the EFSA were ultimately adopted by the Council on 29 January 2002 - after a 'stormy debate' between the Member States and the European Parliament (Clergeau, 2005, p. 129). The reforms significantly increased supranational discretion over food safety policy and health policy: 'For the first time, the notion of foodstuff was defined by Community law and included agricultural products. Unification of food legislation thus became irreversible' (Clergeau, 2005, p. 129).

\section{European Integration in Response to the Euro Crisis 2010-13}

After the outbreak of the Greek sovereign debt crisis in late 2009, the European Council emphasized the European dimension of that crisis for the first time on 11 February 2010 (European Council, 2010a). This marks the starting point of the Euro Crisis, the most severe crisis in the EU's history (Schimmelfennig, 2017). Rising fears of sovereign default in Southern Europe were mirrored in the sharp increase of public attention for the issue of 'sovereign debt'. In the six newspapers under investigation here, the average number of newspaper articles per month on this issue rose from about 13 articles in the two years before the outbreak of the Euro Crisis to 57 articles per month per newspaper during the crisis. In other words, every newspaper covered the issue of sovereign debt on average on every second working day before the crisis. During the 44 months of the Euro Crisis, however, roughly two articles on sovereign debt appeared on every working day in each newspaper. This corresponds with scholarly findings and arguments on considerable politicization of European politics during the Euro Crisis (see Rauh and Zürn, 2014). 
As theoretically expected in hypothesis $\mathrm{H} 1$, high levels of public attention to the underlying problems in the EU's system of fiscal and economic governance instantaneously set policy change in the European Economic and Monetary Union (EMU) on the political agenda. By 25 March 2010, the heads of state and government of the euro area expressed their willingness to set up an institutional emergency mechanism for euro area members in need and moreover recognized a need 'to strengthen and complement the existing [legal] framework to ensure fiscal sustainability in the euro zone and enhance its capacity to act in times of crises' (European Council, 2010b). The fact that the European Council alone discussed the legislative details of the EU's crisis response in 20 of its 24 meetings (ten of them extraordinary or informal) in the 44 months between 11 February 2010 and 15 October 2013 underlines the high salience of policy change in times of the Euro Crisis. As expected, this represents a major change compared to the pre-crisis period: in 2006 and 2007, before the outbreak of the World Financial and Economic Crisis in 2008, the EU heads of state and government gathered only eight times. In other words, European leaders met on average every three months in pre-crisis times, but every two months during the crisis.

In line with hypothesis $\mathrm{H} 2 \mathrm{~b}$, integration preferences on EMU-related policies have been voiced by domestic elites of the respective countries. For instance, after the outbreak of the Euro Crisis in February 2010, the governments of Germany and the UK initially resisted the French proposal of a joint European rescue mechanism for Greece (Wasserfallen et al., 2017) in reaction to pressure by domestic elites (Financial Times, 2014; The Guardian, 2010). During national preference formation on a fiscal emergency mechanism for the euro area, the later European Stability Mechanism (ESM), the German government took up proposals by senior Bundesbank staff on improved economic co-ordination and strengthened fiscal rules and rule enforcement mechanisms (Financial Times, 2014).

Yet, major banks and industrial associations in all three major EU Member States under investigation also forcefully voiced their proposals for the resolution of the Euro Crisis during the years between 2010 and 2013. For instance, the reluctant change in the German government's position in the subsequent months can be explained by continuous lobbying efforts from private German banks, which were heavily invested in Greek sovereigns (see Degner, 2016, p. 27) and consequently faced severe, obvious and direct costs from a potential 'Grexit', the unorganized Greek exit from the euro area. German industrial associations in turn feared a renewed credit crunch and the disturbance of the Single Market in case of non-action (FAZ, 2010), and consequently lobbied the German government as well. ${ }^{7}$ Concerning financial market regulation, both German and French private banks aimed to achieve harmonious supervision (Howarth and Quaglia, 2016, p. 455f). The German government, however, tried to avoid conflicts with the local and regional political patrons of the smaller Sparkassen (savings banks), which were strongly opposed to supranational control. Consequently, Germany preferred ECB oversight for large banks only. France, which has a much more centralized banking sector, by contrast supported fully harmonized banking supervision (Howarth and Quaglia, 2016, p. 455f).

How can the important role of well-organized economic interests in national preference formation on the 'core state powers' covered by the EMU be explained? Arguably, the exceptionally high degree of political integration in monetary policy (Leuffen et al.,

\footnotetext{
${ }^{7}$ See the "Joint Call for deeper European Integration" of the German BDI, the Italian Confindustria and the French Medef, available online at: http://www.themenportal.de/politik/gemeinsamer-aufruf-von-bdi-confindustria-und-medef-84090.
} 
2013, Ch. 6) and the strong integration of European financial markets at the outset of the crisis (Howarth and Quaglia, 2016) turn the EMU into an area that falls somewhere in between a classical 'core state power' and an internal market-related policy area. When economic actors are directly affected by integration decisions in the EMU, they have a strong incentive to approach their governments with proposals for policy change that maximizes their interests.

Concerning governmental cost-benefit analyses of the various proposals to reform EMU, Chancellor Merkel (2010) justified her government's consent to the introduction of a fiscal emergency mechanism, which de facto circumvented the 'no-bailout clause' of the EU treaties (Art. 125.1 TFEU), with the extremely high material costs of any other political strategy, particularly the introduction of 'Eurobonds'. In view of strong public opposition to fiscal aid measures (Bechtel et al., 2014), her government yet tried to reduce domestic ratification costs by conditioning fiscal aid to the adoption of EMU reforms aiming at stronger economic co-ordination and effective sanctioning mechanism for Euro members in breach of fiscal rules (Bulmer, 2014, p. 1,254). The French government in turn tried to cushion the German demand for fiscal rigidity with their concept of a 'gouvernement économque' (Le Figaro, 2010), which was popular among French political elites across the political spectrum (Howarth, 2007).

The British government finally tried to reconcile the integration-friendly positions of their domestic banks and other private economic interests in the City of London (Levitt, 2012 , p. 1,275) on the one hand and the integration-sceptical or outright-hostile positions among the country's political elites, including large parts of the ruling Conservative party, by fostering 'differentiated integration' (Leuffen et al., 2013) in the sense of further integration of the euro area without the participation of the UK.

While the Euro Crisis put the sheer existence of the European integration project into question and stirred the public and academic debate on European disintegration (Vollard, 2014; Webber, 2017), EU and/or euro area Member States ultimately adopted a range of decisions that predominantly deepened integration in fiscal and economic policy (Schimmelfennig, 2015b, p. 190ff), but also concerned financial market and banking regulation (Howarth and Quaglia, 2016). In order to create a legal base for the newly set up European Stability Mechanism (ESM), the EU moreover changed its primary law by adding Art. 136.3 TFEU to the treaties. The adoption of the "single supervisory mechanism' for large banks in the euro erea on 22 October 2013 arguably marks the end point of the Euro Crisis. Even though the economic situation in Greece and other southern EU Member States, particularly Italy, remained critical in the following years (Copelovitch et al., 2016, p. 816), the risk of contagion in the euro area disappeared in the months after that decision was taken (see Dawson et al., 2015, p. 1).

In line with hypothesis H4b, the 'Franco-German engine' (Leuffen et al., 2012) played a key role during the negotiations on the just mentioned reforms between 2010 and 2013: The governments of the two most important euro area Member States repeatedly issued joint proposals or statements that pre-structured EU level negotiations. ${ }^{8}$ The famous Deauville declaration of 18 October 2010, ${ }^{9}$ which laid out the 'Grand Design' for the EU's crisis

\footnotetext{
${ }^{8}$ See, for example, the Franco-German Communiqué of 7 August 2011, available online at http://www.france-allemagne.fr/ Gemeinsames-deutsch-franzosisches, 6215.html, or the Franco-German Letter to the President of the European Council of 8 December 2011, available online at https://franceintheus.org/spip.php?article3029.

${ }^{9}$ Available online at: http://www.eu.dk/ /media/files/eu/franco_german_declaration.ashx?la=da.
} 
response, symbolizes the Franco-German dominance in the early phase of crisis resolution (Financial Times, 2010; Schild, 2013a).

However, despite the 'Merkozy label' (Bulmer, 2014, p. 1,255) of many initiatives, Germany was the predominant partner of the duo. The measures to enhance fiscal prudence and economic co-ordination across the euro area (for example, Six-Pack, TwoPack, Fiscal Compact) mirrored in large parts the preferred strategies of the Bundesbank, the CDU/CSU parliamentary faction in the Bundestag (Degner and Leuffen, 2016), and a majority in the German political and academic elites (Mussler, 2011, p. 56). The decision to set up a banking union under the aegis of the ECB was shaped in a way that it did not concern the German Sparkassen (Howarth and Quaglia, 2014, p. 131). Even if Germany could not achieve all its policy goals, it still played 'both a dominant role and a leadership role' during the crisis (Bulmer, 2014, p. 1,255).

In line with hypothesis $\mathrm{H} 4 \mathrm{~b}$, the success of the German government in interstate negotiations can be attributed to its great economic power (Bulmer, 2014, p. 1,251ff) and its large contribution to the fiscal aid measures (about 27.1 per cent of the respective total sums). Although France - like all other euro area Member States - held a veto position in most decisions, the economic fallout of the Euro Crisis weakened its bargaining position (Schild, 2013b, p. 6). Most of its Southern European partners, with Italy being the only exception, received fiscal aid programmes during the crisis and were therefore unable to resist the German pressure for stricter fiscal discipline and greater economic co-ordination. The government of the non-euro member Great Britain meanwhile stood at the sidelines of the intergovernmental negotiations, and repeatedly found itself isolated amongst its partners throughout the Euro Crisis (Degner, 2016, p. 31ff).

While the Commission and the European Parliament, as theoretically expected in hypothesis $\mathrm{H} 4 \mathrm{~b}$, did not play a significant role in EU decision-making during the Euro Crisis (Hodson, 2013, p. 312; Schimmelfennig, 2012, p. 407f), the supranational ECB did. ECB president Mario Draghi's (2012) famous 'whatever it takes' speech and the central bank's extraordinary open market activities to restore sustainable interest rates for southern euro area members underlined the ECB's willingness to act as a 'lender of last resort' for the euro area (Henning, 2015). Moreover, the ECB's advocacy for more centralized banking supervision and resolution from early 2012 onwards was crucial to 'shift national preferences and European Council politics' towards Banking Union (De Rynck, 2016, p. 130). This is clearly at odds with the expectation formulated in H4b. Yet, once again the high degree of integration in the EU's monetary policy (cf. Leuffen et al., 2013, Ch.6) turned the policy areas covered by the EMU away from the ideal of a 'core state power'. The EU treaties, in fact, provided the ECB with monetary policy tools, for example, the power to purchase sovereign bonds at secondary markets, which it could - and did - use during the Euro Crisis to shape fiscal or macro-economic policy reforms in line with its preferences.

\section{Conclusions: Never Let a Serious Crisis Go to Waste...}

This article has investigated how crises cause European integration. The in-depth analysis of two of the most severe crises in the EU's history, the BSE Crisis and the Euro Crisis, supports the idea that a four-part causal mechanism is at work. 
First, crises instantaneously turned previously neglected problems such as the link between BSE and the human VCJD desease or excessive government indebtedness into highly salient issues for re-election seeking national governments. In both cases, weaknesses of European policies and institutions became obvious, so that legislative reforms became top priorities on the political agendas of the Member States. This fits with the liberal intergovernmentalist understanding of European integration as a stop-and-go process that is punctuated by important events, rather than a polity that is incrementally deepening through continuous, functional spillovers.

Second, high attention indeed opened windows of opportunity for either well-organized, resource-rich domestic actors or political elites to approach their governments with policy proposals that tackled the unveiled problems and implied further integration. While economic interest groups like banks or farmers associations and consumer protection associations were particularly active when the BSE Crisis affected internal market policies, political elites like members of parliament or representatives of domestic institutions like the German Bundesbank dominated preference formation on the integration of core state powers during the Euro Crisis. Private banks and industrial association also played important roles during the latter crisis, which can be explained with the high degree of integration in the EU's financial markets, which translated into clear and direct costs of (the potential lack of) a European response to the crisis.

Third, the governments of the EU's 'big three', France, Germany and the United Kingdom, ultimately considered policy proposals implying further integration as least costly in terms of both material and ratification costs. The revealed problem yet had to be perceived as a truly European threat; while it only took a few weeks for European politicians to realize that 'if the Euro fails, Europe fails', Member State governments needed four years to realize that the threat to their societies posed by BSE could not be contained by an export ban on British cattle and beef or by the mere inclusion of a European competency for health policy in the Amsterdam treaty. Only when BSE was finally detected in indigenous German and French cattle in late 2000 and government cost-benefit calculations changed in favour of harmonizing food safety policy in the EU, did the adoption of secondary law measures, notably the European Food Law and the set up of the European Food Safety Authority, became feasible.

Fourth, interstate bargaining on the ultimate legislative EU response to a crisis was characterized by hard intergovernmental bargaining. Beyond that, and as theoretically expected, the Commission and the European Parliament significantly shaped the decisions adopted in response to the BSE Crisis by their numerous, partially far-reaching proposals for policy change in the affected policy areas related to the internal market. Diverging from the model's expectations, however, neither the Commission nor the European Parliament, but the European Central Bank played a crucial role in the politics of 'saving the euro'. Yet, monetary policy in the euro area has been exclusively governed by the ECB since 1999, while fiscal and macro-economic policies essentially remained a domain of the Member States. In that sense, the Euro Crisis exhibits features of a crisis that affected both core state powers and policy areas related to the EU's internal market. Rather than undermining the theoretical model, the finding of an exceptionally strong ECB underlines the character of the EMU as an area with traits of both a classical "core state power' and an internal market-related policy area. 
In sum, the adapted liberal intergovernmentalist model appears well prepared to explain European integration in response to severe crises. Further research should test the model on further cases to provide additional evidence that public attention, governmental power and, in case, supranational activism drive European integration in response to crises. A particular focus should lie on the varying role of supranational actors across policy areas. Gaining knowledge in this area is of crucial importance in times when the presence of multiple crises, unfortunately, seems to have become the 'new normal' for the EU (Haughton, 2016).

\section{Correspondence:}

Hanno Degner

University of Konstanz

Department of Politics and Public Administration

PO Box 83 / Universitätsstraße 10

D-78457 Konstanz

email: hanno.degner@uni-konstanz.de

\section{References}

Ackrill, R., Kay, A. and Zahariadis, N. (2013) 'Ambiguity, Multiple Streams, and EU Policy'. Journal of European Public Policy, Vol. 20, No. 6, pp. 871-87.

BBC (1997) 'BSE - The Story So Far', 5 December. Available online at: http://news.bbc.co.uk/2/ hi/special_report/1997/bse/37232.stm (accessed 1 September 2017).

Beach, D. and Pedersen, R.B. (2013) Process-Tracing Methods. Foundations and Guidelines (Ann Arbor, MI: University of Michigan Press).

Bechtel, M.M., Hainmueller, J. and Margalit, Y. (2014) 'Preferences for International Redistribution: The Divide over the Eurozone Bailouts'. American Journal of Political Science, Vol. 58, No. 4, pp. 835-56.

Beck, M. and Asenova, D. (2007) 'BSE Crisis and Food Safety Regulation: A Comparison of the UK and Germany', The York Management School Working Paper No. 38 (York: University of York).

Boin, A., 't Hart, P., Stern, E. and Sundelius, B. (2005) The Politics of Crisis Management. Public Leadership under Pressure (Cambridge: Cambridge University Press).

Boin, A., Ekengren, M. and Rhinard, M. (2013) The European Union as Crisis Manager. Patterns and Prospects (Cambridge: Cambridge University Press).

Boin, A. and Rhinard, M. (2008) 'Managing Transboundary Crises: What Role for the European Union?' International Studies Review, Vol. 10, No. 1, pp. 1-26.

Bulmer, S.J. (2014) 'Germany and the Eurozone Crisis: Between Hegemony and Domestic Politics'. West European Politics, Vol. 37, No. 6, pp. 1244-63.

Clergeau, C. (2005) 'European Food Safety Policies. Between a Single Market and a Political Crisis'. In Steffen, M. (ed.) Between a Single Market and Political Crisis. Community Policies and Food Safety (London: Routledge), 113-33.

Copelovitch, M., Frieden, J.A. and Walter, S. (2016) 'The Political Economy of the Euro Crisis'. Comparative Political Studies, Vol. 49, No. 7, pp. 811-40.

Dawson, M., Enderlein, H. and Joerges, C. (2015) 'Introduction: The Governance of the Transformation of Europe's Economic, Political, and Constitutional Constellation since the Euro Crisis'. In Dawson, M., Enderlein, H. and Joerges, C. (eds) Beyond the Crisis. The Governance of Europe's Economic, Political, and Legal Transformation (Oxford: Oxford University Press), 1-11. 
De Rynck, S. (2016) 'Banking on a Union: The Politics of Changing Eurozone Banking Supervision'. Journal of European Public Policy, Vol. 23, No. 1, pp. 119-35.

Degner, H. (2016) 'European Integration in Response to the 'Euro Crisis' 2010-2013'. In Saurugger, S. and Terpan, F. (eds) Crisis and Institutional Change in Regional Integration (London: Routledge), 23-40.

Degner, H. and Leuffen, D. (2016) 'Keynes, Friedman, or Monnet? Explaining Parliamentary Voting Behaviour on Fiscal Aid for Euro Area Member States'. West European Politics, Vol. 39, No. 6, pp. 1139-59.

Dinan, D., Nugent, N. and Paterson, W.E. (eds) (2017) The European Union in Crisis (Houndmills: Palgrave Macmillan).

Draghi, M. (2012) Speech by Mario Draghi, President of the European Central Bank at the Global Investment Conference, London, 26 July. Available online at: https://www.ecb.europa.eu/ press/key/date/2012/html/sp120726.en.html (accessed 1 September 2017).

European Commission (1996) 'The European Union "A View from the Top"', Report Prepared by EOS Gallup Europe, Brussels. Available online at: http://ec.europa.eu/public_opinion/flash/fl_ 39_en.pdf (accessed 1 September 2017).

European Commission (1997) 'The General Principles of Food Law in the European Union', COM (97) 176 final, 30 April. Available online at: http://eur-lex.europa.eu/LexUriServ/ LexUriServ.do?uri=COM:1997:0176:FIN:EN:PDF (accessed 1 June 2017).

European Commission (2000) 'White Paper on Food Safety', COM (1999) 719 final, 12 January. Available online at: http://ec.europa.eu/dgs/health_food-safety/library/pub/pub06_en.pdf (accessed 1 August 2017).

European Council (2010a) 'Statement by the Heads of State or Government of the European Union', Brussels, 11 February. Available online at: http://www.consilium.europa.eu/en/european-council/pdf/20100211-Statement-by-the-Heads-of-State-or-Government-of-the-European-Union-on-Greece-EN_pdf/ (accessed 1 September 2017).

European Council (2010b) 'Statement of the Heads of State and Government of the Euro Area', Brussels, 25 March. Available online at: http://www.consilium.europa.eu/uedocs/cms_data/ docs/pressdata/en/ec/113563.pdf (accessed 1 September 2017).

European Parliament (1997) Report A4-0362/97 (Strasbourg: EP). Available online at: http:// www.europarl.europa.eu/conferences/19981130/bse/a4002097_en.htm (accessed 1 June 2017).

FAZ (2000) 'Europa und die Seuche', 22 November.

FAZ (2001) 'Der Bauernverband wehrt sich und zeigt sich zur Zusammenarbeit mit der Regierung bereit', 12 January.

FAZ (2010) 'Koalition will Banken an Kosten der Krise beteiligen', 22 March. Avaliable online at: http://www.faz.net/aktuell/wirtschaft/wirtschaftspolitik/eine-zumutbare-abgabe-koalitionwill-banken-an-kosten-der-krise-beteiligen-1957667.html. (accessed 1 September 2017).

Financial Times (2010) 'Franco-German Bail-out Pact Divides EU', 24 October. Available online at: https://www.ft.com/content/56984290-df96-11df-bed9-00144feabdc0. (accessed 1 September 2017).

Financial Times (2014) 'If the Euro Falls, Europe Falls', 15 May. Available online at: http://on.ft. com/1t5oiGx. (accessed 1 September 2017).

Fischer, R. (2009) Die Europäische Union auf dem Weg zu einer vorsorgenden Risikopolitik? (Wiesbaden: VS Verlag für Sozialwissenschaften).

Genschel, P. and Jachtenfuchs, M. (eds) (2013) Beyond the Regulatory Polity? The European Integration of Core State Powers (Oxford: Oxford University Press).

Genschel, P. and Jachtenfuchs, M. (2016) 'More Integration, Less Federation: The European Integration of Core State Powers'. Journal of European Public Policy, Vol. 23, No. 1, pp. $42-59$. 
Gerring, J. (2007) Case Study Research. Principles and Practices (Cambridge: Cambridge University Press).

Haughton, T. (2016) 'Is Crisis the New Normal? The European Union in 2015'. JCMS, Vol. 54, Annual Review, pp. 5-7.

Hedström, P. and Ylikoski, P. (2010) 'Causal Mechanisms in the Social Sciences'. Annual Review of Sociology, Vol. 36, No. 1, pp. 49-67.

Henning, C.R. (2015) 'The ECB as a Strategic Actor: Central Banking in a Politically Fragmented Monetary Union', School of International Service Research Paper No. 1/2015 (Washington, DC: American University).

Hodson, D. (2013) 'The Little Engine That Wouldn't: Supranational Entrepreneurship and the Barroso Commission'. Journal of European Integration, Vol. 35, No. 3, pp. 301-14.

Hooghe, L. and Marks, G. (2009) 'A Postfunctionalist Theory of European Integration: From Permissive Consensus to Constraining Dissensus'. British Journal of Political Science, Vol. 39, No. 1, pp. 1-23.

Howarth, D.J. (2007) "Making and Breaking the Rules: French Policy on EU 'gouvernement économique'. Journal of European Public Policy, Vol. 14, No. 7, pp. 1061-78.

Howarth, D.J. and Quaglia, L. (2014) 'The Steep Road to European Banking Union: Constructing the Single Resolution Mechanism'. JCMS, Vol. 52, Annual Review, pp. 125-40.

Howarth, D.J. and Quaglia, L. (2016) 'Internationalised Banking, Alternative Banks and the Single Supervisory Mechanism'. West European Politics, Vol. 39, No. 3, pp. 438-61.

Ioannou, D., Leblond, P. and Niemann, A. (2015) 'European Integration and the Crisis: Practice and Theory'. Journal of European Public Policy, Vol. 22, No. 2, pp. 155-76.

Kingdon, J.W. (2003 [1984]) Agendas, Alternatives, and Public Policies (New York: Longman).

Knowles, T., Moody, R. and McEachern, M.G. (2007) 'European Food Scares and their Impact on EU Food Policy'. British Food Journal, Vol. 109, No. 1, pp. 43-67.

Krapohl, S. and Zureck, K. (2006) 'The Perils of Committee Governance: Intergovernmental Bargaining during the BSE Scandal in the European Union'. European Integration online Papers, Vol. 10, No. 2, pp. 1-16.

Larsson, P., Hagström Frisell, E. and Olsson, S. (2009) 'Understanding the Crisis Management System of the European Union'. In Olsson, S. (ed.) Crisis Management in the European Union. Cooperation in the Face of Emergencies (Heidelberg: Springer), 1-16.

Le Figaro (2010) 'Un gouvernement Èconomique pour l'Europe', 13 February.

Leuffen, D., Degner, H. and Radtke, K. (2012) 'Which Mechanics Drive the 'Franco-German Engine'? An Analysis of How and Why France and Germany Have Managed to Shape Much of Today's EU'. L'Europe en formation, Vol. 53, No. 4, pp. 47-83.

Leuffen, D., Rittberger, B. and Schimmelfennig, F. (2013) Differentiated Integration. Explaining Variation in the European Union (Basingstoke: Palgrave Macmillan).

Levitt, M. (2012) 'The City and EMU'. International Affairs, Vol. 88, No. 6, pp. 1261-75.

Lodge, M. and Wegrich, K. (eds) (2012) The Executive at Work during Times of Crisis (Basingstoke: Palgrave Macmillan).

Mayer, D. (2004) Gesundheitsschutz in der Europäischen Gemeinschaft am Beispiel von BSE. Eine Untersuchung der Kompetenzen, Durchführung und Entwicklung anhand der Maßnahmen der Gemeinschaft zur Eindämmung des BSE-Erregers (Frankfurt/Main: Peter Lang).

Merkel, A. (2010) 'Regierungserklärung zu den Maßnahmen zur Stabilisierung des Euro vor dem Deutschen Bundestag', Berlin, 19 May. Available online at: http://dipbt.bundestag.de/dip21/ btp/17/17042.pdf (accessed 1 September 2017).

Milzow, K. (2012) National Interests and European Integration. Discourse and Politics of Blair, Chirac and Schröder (Basingstoke: Palgrave Macmillan).

Missiroli, A. (2006) 'Disasters Past and Present: New Challenges for the EU'. Journal of European Integration, Vol. 28, No. 5, pp. 423-36. 
Moravcsik, A. (1993) 'Preferences and Power in the European Community: A Liberal Intergovernmentalist Approach'. JCMS, Vol. 31, No. 4, pp. 473-524.

Moravcsik, A. (1998) The Choice for Europe. Social Purpose and State Power from Messina to Maastricht (Ithaca, NY: Cornell University Press).

Moravcsik, A. and Schimmelfennig, F. (2009) 'Liberal Intergovermentalism'. In Wiener, A. and Diez, T. (eds) European Integration Theory (Oxford: Oxford University Press), 67-87.

Mussler, W. (2011) 'EU Economic Governance: the German View'. In Jamet, J.-F., Mussler, W. and De Corte, S. (eds) EU Economic Governance: The French and German Views (Brussels: Centre for European Studies), 43-74.

Peterson, J. and Bomberg, E. (1999) Decision-Making in the European Union (Houndmills: Macmillan Press).

Rauh, C. and Zürn, M. (2014) 'Zur Politisierung der EU in der Krise'. In Heidenreich, M. (ed.) Krise der europäischen Vergesellschaftung? Soziologische Perspektiven (Wiesbaden: VS Verlag für Sozialwissenschaften), 121-45.

Saurugger, S. (2016) 'Politicisation and Integration through Law: Whither Integration Theory?' West European Politics, Vol. 39, No. 5, pp. 933-52.

Saurugger, S. and Terpan, F. (eds) (2016) Crisis and Institutional Change in Regional Integration (London: Routledge).

Schild, J. (2013a) 'Leadership in Hard Times. Germany, France, and the Management of the Eurozone Crisis'. German Politics and Society, Vol. 31, No. 1, pp. 24-47.

Schild, J. (2013b) 'Politischer Führungsanspruch auf schwindender Machtbasis: Frankreichs Europapolitik unter François Hollande'. Integration, Vol. 22, No. 1, pp. 1-14.

Schimmelfennig, F. (2012) 'Zwischen Neo- und Postfunktionalismus: Die Integrationstheorien und die Eurokrise'. Politische Vierteljahresschrift, Vol. 53, No. 3, pp. 394-413.

Schimmelfennig, F. (2015a) 'Efficient Process Tracing. Analyzing the Causal Mechanisms of European Integration'. In Bennett, A. and Checkel, J.T. (eds) Process Tracing. From Metaphor to Analytical Tool (Cambridge, Cambridge University Press), 98-125.

Schimmelfennig, F. (2015b) 'Liberal Intergovernmentalism and the Euro Area Crisis'. Journal of European Public Policy, Vol. 22, No. 2, pp. 177-95.

Schimmelfennig, F. (2017) 'Theorising Crisis in European Integration'. In Dinan, D., Nugent, N. and Paterson, W.E. (eds) The European Union in Crisis (Houndmills: Palgrave Macmillan), 316-35.

Schmitter, P.C. (2012) 'European Disintegration? A Way Forward?' Journal of Democracy, Vol. 23, No. 4, pp. 39-46.

Stone Sweet, A. (2004) The Judicial Construction of Europe (Oxford: Oxford University Press).

Tallberg, J. (2008) 'Bargaining Power in the European Council'. JCMS, Vol. 46, No. 3, pp. 685-708.

The Guardian (2010) 'Don't Laugh at Europe's Woes. The Travails Facing Greece are also Ours'. 14 February. Avaliable online at: https://www.theguardian.com/commentisfree/2010/feb/14/ will-hutton-greece-euro?index=1. (accessed 1 September 2017).

Tosun, J., Wetzel, A. and Zapryanova, G. (2014) 'The EU in Crisis: Advancing the Debate'. Journal of European Integration, Vol. 36, No. 3, pp. 195-211.

Trauner, F. and Ripoll Servent, A. (2016) 'The Communitarization of the Area of Freedom, Security and Justice: Why Institutional Change does not Translate into Policy Change'. JCMS, Vol. 54, No. 6, pp. 1417-32.

van Middelaar, L. (2013) The Passage to Europe. How a Continent Became a Union (New Haven: Yale University Press).

van Zwanenberg, P. and Millstone, E. (2005) BSE: Risk, Science, and Governance (Oxford: Oxford University Press).

Vollard, H. (2014) 'Explaining European Disintegration'. JCMS, Vol. 52, No. 5, pp. 1142-59. 
Vos, E. (2000) 'EU Food Safety Regulation in the Aftermath of the BSE Crisis'. Journal of Consumer Protection, Vol. 23, No. 3, pp. 227-55.

Wasserfallen, F., Leuffen, D., Kudrna, Z. and Degner, H. (2017) 'EU Member States Positions for Economic and Fiscal Integration: Introducing New Data and the Special Issue', Paper presented at the EMUIChoices Midterm Conference, Rome, 6-7 July.

Webber, D. (2017) 'Can the EU Survive?' In Dinan, D., Nugent, N. and Paterson, W.E. (eds) The European Union in Crisis (Houndmills: Palgrave Macmillan), 336-59.

Zahariadis, N. (2014) 'Ambiguity and Multiple Streams'. In Sabatier, P.A. and Weible, C.M. (eds) Theories of the Policy Process (Third edition) (Boulder, CO: Westview), 25-58. 